\title{
Editorial: Retrolental fibroplasia (RLF) unrelated to oxygen therapy
}

In the early days of research into the cause of RLF it was not uncommon at any meeting where oxygen was suggested as the cause, for an indignant ophthalmologist to rise from the floor and report a typical case where to his certain knowledge no supplemental oxygen was given. He would then sink back convinced that he had delivered the coup de grâce to the oxygen theory. Equally challenging were those who claimed to have seen the condition in full-term infants, which seemed to deny any special vulnerability of growing retinal vessels. Although we now know these claims to have been valid, at the time they were stumbling blocks to the early acceptance of the vital importance of prematurity and oxygen. Even in those days, however, it was not to be expected that any process as non-specific as retinal vasoproliferation, already familiarly seen in such conditions as Eales's disease, diabetic retinopathy, sickle cell disease, and pulseless disease, could be explained only by the pathogenesis of RLF.

Indeed, during the passage of two decades since oxygen was proved both clinically and experimentally to be responsible for the vast majority of cases, it has become increasingly evident that an aberrant overgrowth of retinal vessels, following the same three pathological stages as in RLF, may occur in infancy in conditions apparently unconnected with oxygen exposure (Huggert, I954; Brückner, I968; Seedorff, I968), or in fact with prematurity (Reese, 1949; Reese and Blodi, I951 ; Reese and Stepanik, I954; Unsworth, I949; Dixon and Paul, I95I; Minton and Cole, I95I ; Karlsberg, Green, and Patz, I973), or with both (Schlitter, I957; Crome, 1958; Vergez, Dhermy, and Cosson, I966). In histological sections from the eyes of infants in which neovascularization is apparent, it is not difficult to consider such cases to fall within the RLF group, but it is not possible to determine what proportion of cases showing only vitreous bands or retinal detachment, with or without fibrous tissue behind the lens, might have begun in this way. Even persistence of the primary vitreous was at one time confused with RLF (Reese and Payne, 1946). Consequently, this group of conditions can be studied histopathologically only in those sections showing undoubted vasoproliferative retinopathy.

Anencephaly is one of the most striking of these conditions in which the early stages of RLF are closely paralleled (Hirose and Yoshioka, 1957; Cogan, 1963; Andersen, BroRasmussen, and Tygstrup, 1967; Addison, Font, and Manschot, 1972), and it has been suggested that intrauterine anoxia, either primary or secondary, is the causal relationship with RLF (Addison and others, 1972). Intrauterine anoxia was also suggested as the cause of RLF in an infant who had not been given oxygen after birth (Brückner, I968), and such a cause might also have been invoked in a case of RLF in a full-term infant with bilateral hydrocephalus (Karlsberg and others, 1973). 
The pathogenesis of classical RLF, however, is quite distinctive, the vasoproliferation being secondary to anoxia, resulting from closure of the retinal vessels by hyperoxia. If is possible that anoxia in the presence of normally growing and patent vessels mighit directly cause proliferation, although experimentally the matter is controversial. Certainl $\frac{5}{9}$ in those cases mimicking RLF, whether in premature or full-term babies un-exposed to hyperoxia, no evidence has been provided that vaso-obliteration has preceded vasoprō liferation as in RLF, so that the relationship between the two groups is not clear.

It is therefore important that these cases of proliferative retinopathy in infancy should be examined histopathologically with the greatest care (including retinal digests), for when sufficient material has been studied it may be possible to identify the various causal mechanisms.

In this issue we publish a report by Stefani and Ehalt, who have studied in considerable. detail, including a follow-up enquiry, fifteen cases (ten bilateral and five unilateral) collected over the last I9 years and filed in the Department of Pathology, Institute of Ophthalmologyer London, under the heading of "non-oxygen induced retinitis proliferans in full-ternit infants". That is, the cases resembled RLF histologically and yet the infants had not bee given supplemental oxygen at any time and were full-term according to their birth weight and gestational age.

As to be expected, the authors conclude that retinal vasoproliferation in infants is non-specific secondary reaction, occurring not only in RLF but also in a number of pathoo logical conditions. Among their cases they considered the possibilities of Coats's disease, Norrie's disease, falciform retinal detachment, intraocular haemorrhage, battered bab syndrome, congenital retinal detachment, and the association of chromosomal aberrations and teratogenic agents. No classification was possible in some of the cases while the fundar mental cause of the neovascularization was obscure in all.

While further histological studies of this kind may help to clarify the confusing position this is more likely to come about through research aimed at the identification of the dif fusible vasoformative factors which stimulate retinal endothelial proliferation: the recen isolation of such a factor from tumours (tumour angiogenesis factor, TAF) by Folkmain and his colleagues (Folkman, 1971, I972a,b; Brem, Cotran, and Folkman, 1972; Cavallọ. Sade, Folkman, and Cotran, 1972; Gimbrone, Leapman, Cotran, and Folkman, 1972) most encouraging in this respect.

Meanwhile Stefani and Ehalt suggest that the term RLF be wholly reserved for oxygen induced retinopathy in prematurity. While the recommendation is in general acceptable the two variants of RLF already referred to which the term would appear to exclude, must be borne in mind. First, an ambient oxygen concentration even as low as that in air mighe in certain circumstances, injure the immature retina, while the vasculature in full-terñ infants may not always be sufficiently mature to resist hyperoxia. Neither of these possibilitied has, however, been proved; in any event they would clearly come within the classification df RLF since the same pathogenesis is proposed. As suggested by Stefani and Ehalt, an\& advocated in a Lancet annotation in 1958, all other intraocular conditions in infanct characterized by retinal neovascularization, which in all probability are aetiologicall dissimilar, should be set aside until their true nature can be recognized. 


\section{References}

ADDison, D. J., FONT, R. L., and manschot, w. A. (1972) Amer. F. Ophthal., 74, 967

ANDERSEN, S. R., BRO-RASMUSSEN, F., and TYGSTRUP, I. (1967) Ibid., 64, 559

BREM, S., COTRAN, R., and FOLKMAN, J. (1972) F. nat. cancer Inst., 48, 347

BRÜCKNER, H. L. (1968) Arch. Ophthal. (Chicago), 80, 504

cavallo, t., sade, R., folkman, J., and cotran, R. s. (1972) F. Cell Biol., 54, 408

COGAN, D. G. (1963) Trans. ophthal. Soc. U.K., 83, 465

Grome, L. (1958) J. Path. Bact., 75, 163

DIXoN, J. M., and PAUl, E. v. (I95I) Amer. F. Ophthal., 34 no. 5, pt. II, p. I82

FOLKMAN, J. (1971) New Engl. F. Med., 285, 1182

(1972a) Ann. Surg., 175, 409

(1972b) 7. invest. Derm., 59, 40

gimbrone, m. A., Leapman, s. B., cotran, R. s., and folkman, J. (1972) J. exp. Med., 136, 261 HIROSE, K., and Yoshioka, H. (1957) Jap. J. Ophthal., r, 106

HUGGERT, A. (1954) Acta paediat. (Uppsala), 43, 327

kARlsberg, R. G., Green, W. R., and PatZ, A. (1973) Arch. Ophthal. (Chicago), 89, 122

Lancet (1958) Annotation. Retrolental fibroplasia. Lancet, 1, 893

minton, J., and Cole, P. (1951) Brit. med. F., I, 450

REESE, A. B. (1949) Arch. Ophthal. (Chicago), 41, 527

- and BLODI, F. c. (1951) Amer. F. Ophthal., 34, I

and PAYNE, F. (1946) Ibid., 29, I

and STEPANIK, J. (1954) Ibid., 38, 308

SChlitter, K. (1957) Klin. Mbl. Augenheilk., 131, 544

SEEDORFF, T. (1968) Nord. Med., 79, 269

UNSWORTh, A. C. (1949) Trans. Amer. ophthal. Soc., 47, 738

Vergez, A., Dhermy, P., and cosson, c. (1966) Arch. Ophtal. (Paris), 26, 355 